\title{
Pulmonary Macrophage-Targeted Therapies-The Way Forward in Chronic Inflammatory Lung Diseases?
}

\section{Sandra Hodge*}

Department of Thoracic Medicine, Royal Adelaide Hospital, Adelaide, South Australia

It is becoming increasingly evident that pulmonary macrophage dysfunction contributes to disease pathogenesis in a variety of chronic lung diseases including chronic obstructive pulmonary disease (COPD) [1], bronchiolitis obliterans syndrome (BOS) following lung transplantation [2], cystic fibrosis (CF) [3] and severe asthma (NEA) [4]. An abnormal accumulation of apoptotic bronchial epithelial cells with an associated defect in the phagocytic ability of neighboring macrophages (efferocytosis) can lead to secondary necrosis of the uncleared apoptotic material with pro-inflammatory effects $[5,6]$. Specific therapeutic targeting of the macrophage dysfunction is being increasingly studied. The actual progression of this strategy to clinical use is however still very much in the early stages and much of our knowledge of the potential impact of macrophage-targeted therapies has evolved in retrospect rather than from a direct developmental approach.

The emerging body of evidence suggests that that the use of longterm macrolide therapy is both feasible and may offer useful clinical outcomes in chronic lung diseases, including COPD, BOS and NEA [6$8]$, while results in CF have been inconclusive $[9,10]$. The mechanism of action of macrolides in this regard may be through their effects on macrophage function [6-8]. In a small uncontrolled study using lowdose azithromycin in COPD subjects the principal findings were a significant increase in the efferocytosis capacity of alveolar macrophages and a reduction in the percentage of apoptotic airway epithelial cells obtained by airway brushing [7]. A role for phosphatidyserine (PS) in these effects was shown [8].

Pulmonary macrophages may contribute to the relative insensitivity to cortocosteroids in chronic lung diseases $[11,12]$. Dexamethasone has been shown to improve efferocytosis [13] while in patients with severe asthma, defective efferocytosis was improved after a course of high dose steroids [14]. In COPD, lung macrophages have reduced expression of the epigenetic modifying enzyme histone deacetylase 2 (HDAC2) and this is associated with increased expression of inflammatory genes and also resistance to corticosteroids [12].

Statins also have been shown to improve macrophage phagocytic function mediated in part by their inhibitory effects on RhoA [15]. In COPD, there is evidence of an improved mortality rate following treatment with statins [16]; however, whether the effects of statins on macrophage function will translate to human clinical benefit is uncertain, as the doses used to achieve the in vitro effects were higher than those typically used clinically.

The process of efferocytosis involves signaling through macrophage surface receptors that include MER tyrosine kinase (MERTK), GAS6, milk fat globule epidermal growth factor 8 (MFG-E8) and several putative PS receptors including a $G$ protein-coupled receptor, BAI1 (brain-specific angiogenes 1), TIM-1 and TIM-4. Activation of protein kinase $C B I I$ is required for efferocytosis. Scavenger receptors (mannose receptor, SRA11 (type AII), MARCO (class A) CD36 (class B)) facilitate the phagocytosis of modified protein on apoptotic cells. Dysregulated expression of macrophage receptors in COPD has been reported $[6,7,17-19]$ and these may provide suitable targets for macrophagetargeted therapies. Whether epigenetic regulation of the various receptors alters their ligand-binding properties also remains unclear, and there is a need for characterizing epigenetic signatures of relevant genes in macrophages isolated from the various patient groups.

More recently, strategies are being pursued that are more specifically directed towards macrophage function, such as the use of mannosebinding lectin (MBL). MBL plays a key role in regulating efferocytosis and it is expressed at reduced levels in the airway in COPD or BOS $[2,20]$. Human and animal studies support the potential role for MBL in improving phagocytosis and reducing inflammation as a therapeutic strategy for airways disease [20]. Further studies using anti-oxidants with a resultant improvement in macrophage function in smoke exposed mice have also been reported [21].

Compelling evidence is thus emerging for the role of defective pulmonary macrophage function in the pathogenesis of chronic inflammatory airways diseases, and it is also becoming clear that several therapies with established clinical efficacy for various conditions may be exerting some of their beneficial effects via modulation of macrophage function. Greater understanding of the clinical consequences of defective macrophage function and its modulation by therapeutic agents will progress the development of specific macrophage-targeted therapies with complementary or synergistic benefits to established therapies.

\section{References}

1. Hodge S, Hodge G, Scicchitano R, Reynolds PN, Holmes M (2003) Alveolar macrophages from subjects with COPD are deficient in their ability to phagocytose apoptotic airway epithelial cells. Immunol Cell Biol 81: 289-296.

2. Hodge S, Dean M, Hodge G, Holmes M, Reynolds PN (2011) Decreased efferocytosis and mannose binding lectin in the airway in bronchiolitis obliterans syndrome. J Heart Lung Transplant 30: 589-595.

3. Vandivier RW, Richens TR, Horstmann SA deCathelineau AM, Ghosh M, et al. (2009) Dysfunctional cystic fibrosis transmembrane conductance regulator inhibits phagocytosis of apoptotic cells with proinflammatory consequences. Am J Physio Lung Cell Mol Physiol 297: 677-686.

4. Bhavsar P, Hew M, Khorasani N, Torrego A, Barnes PJ, et al. (2008) Relative corticosteroid insensitivity of alveolar macrophages in severe asthma compared with non-severe asthma. Thorax 63: 784-790.

5. Vandivier RW, Henson PM, Douglas IS (2006) Burying the dead: the impact of failed apoptotic cell removal (efferocytosis) on chronic inflammatory lung disease. Chest 129: 1673-1682.

6. Katoh S, Matsubara Y, Taniguchi H, Fukushima K, Mukae H, et al. (2001) Characterization of CD44 expressed on alveolar macrophages in patients with diffuse panbronchiolitis. Clin Exp Immunol 126: 545-550.

*Corresponding author: Sandra Hodge, Department of Thoracic Medicine, Royal Adelaide Hospital, Adelaide, South Australia, E-mail: Sandra.Hodge@health.sa.gov.au

Received February 29, 2012; Accepted March 03, 2012; Published March 05 2012

Citation: Hodge S (2012) Pulmonary Macrophage-Targeted Therapies-The Way Forward in Chronic Inflammatory Lung Diseases?. J Pulmonar Respirat Med 2:e105. doi:10.4172/2161-105X.1000e105

Copyright: (C) 2012 Hodge S. This is an open-access article distributed under the terms of the Creative Commons Attribution License, which permits unrestricted use, distribution, and reproduction in any medium, provided the original author and source are credited. 
Citation: Hodge S (2012) Pulmonary Macrophage-Targeted Therapies-The Way Forward in Chronic Inflammatory Lung Diseases?. J Pulmonar Respirat Med 2:e105. doi:10.4172/2161-105X.1000e105

7. Hodge S, Hodge G, Jersmann H, Matthews G, Ahern J, et al. (2008) Azithromycin Improves Macrophage Phagocytic Function and Expression of Mannose Receptor in chronic obstructive pulmonary disease. Am J Respir Crit Care Med 178: 139148.

8. Yamaryo T, Oishi K, Yoshimine H, Tsuchihashi Y, Matsushima K, et al. (2003) Fourteen-member macrolides promote the phosphatidylserine receptor-dependent phagocytosis of apoptotic neutrophils by alveolar macrophages. Antimicrob Agents Chemother 47: 48-53

9. Zarogoulidis P, Papanas N, Kioumis I, Chatzaki E, Maltezos E, et al. (2011) Macrolides: from in vitro anti-inflammatory and immunomodulatory properties to clinical practice in respiratory diseases. Eur J Clin Pharmacol.

10. Robinson P, Schechter MS, Sly PD, Winfield K, Smith J, et al. (2012) Clarithromycin therapy for patients with cystic fibrosis: A randomized controlled trial. Pediatr Pulmonol.

11. Barnes PJ (2011) Glucocorticosteroids: current and future directions. $\mathrm{Br}$ Pharmacol 163: 29-43.

12. Marwick JA, Adcock IM, Chung KF (2010) Overcoming reduced glucocorticoid sensitivity in airway disease: molecular mechanisms and therapeutic approaches. Drugs 70: 929-948.

13. McColl A, Bournazos S, Franz S, Perretti M, Morgan BP, et al. (2009) Glucocorticoids induce protein S-dependent phagocytosis of apoptotic neutrophils by human macrophages. J Immunol 183: 2167-2175.

14. Huynh ML, Malcolm KC, Kotaru C, Tilstra JA, Westcott JY, et al. (2005) Defective apoptotic cell phagocytosis attenuates prostaglandin E2 and 15-hydroxyeicosatetraenoic acid in severe asthma alveolar macrophages. Am J Respir Criti Care Med 172: 972-979.
15. Morimoto K, Janssen WJ, Fessler MB, McPhillips KA, Borges VM, et al. (2006) Lovastatin enhances clearance of apoptotic cells (efferocytosis) with implications for chronic obstructive pulmonary disease. J Immunol 176: 7657-7665.

16. Ishida W, Kajiwara T, Ishii M, Fujiwara F, Taneichi H, et al. (2007) Decrease in mortality rate of chronic obstructive pulmonary disease (COPD) with statin use: a population-based analysis in Japan. Tohoku J Exp Med 212: 265-273.

17. Kazeros A, Harvey BG, Carolan BJ, Vanni H, Krause A, et al. (2008) Overexpression of apoptotic cell removal receptor MERTK in alveolar macrophages of cigarette smokers. Am J Respir Cell Mol Biol 39: 747-757.

18. Hanayama R, Tanaka M, Miyasaka K, Aozasa K, Koike M, et al. (2004)Autoimmune disease and impaired uptake of apoptotic cells in MFG-E8-deficient mice. Science 304: 1147-1150.

19. Hodge S, Hodge G, Ahern J, Jersmann H, Holmes M, et al. (2007) Smoking alters alveolar macrophage recognition and phagocytic ability: implications in chronic obstructive pulmonary disease. Am J Respir Cell Mol Biol 37: 748-755.

20. Hodge S, Matthews G, Dean MM, Ahern J, Djukic M, et al. (2009) Is there therapeutic role for mannose binding lectin in cigarette smoke-induced lung inflammation? Evidence from a murine model. Am J Respir Cell Mol Biol 42: 235242.

21. Hodge S, Matthews G, Mukaro V, Ahern J, Shivam A, et al. (2011) Cigarette smokeinduced changes to alveolar macrophage phenotype and function are improved by treatment with procysteine. Am J Respir Cell Mol Biol 44: 673-681.

22. Hodge S, Hodge G, Holmes M, Reynolds PN (2005) Increased apoptosis in the airways in COPD persists after smoking cessation. Eur Resp J 25: 447-454. 